\title{
A dor estampada nas imagens da infância: deflagração da injustiça social ou banalização do mal sofrido pelo outro?
}

\section{The pain evidenced on the images of childhood: deflagration of social injustice or trivialization of evil suffered by the other?}

\begin{abstract}
Resumo: Diante das concepções espinosanas sobre os afetos, sentimentos e afecções, este ensaio debate o papel atual das imagens e fotografias que se propõem a expressar/sintetizar/veicular/(res)significar o mal sofrido pelo outro - em particular a criança-, questionando suas possibilidades de organização em torno do bem comum, articulada pela via das lutas sociais, ou como retratos/fragmentos do cotidiano explorados como simples mercadorias no contexto atual do capitalismo e da ideologia neoliberal.
\end{abstract}

Palavras-chave: afetos, imagem, infância, luta social, neoliberalismo

\begin{abstract}
Based on the ideas of Spinoza about the affections, sentiments and affections, this paper discusses the current role of the images and photographs that purport to express / synthesize / vehicular / (re) define the hardship suffered by others - in particular the child-, questioning their ability to organize themselves around common good, articulated by means of social struggles, or as portraits / fragments of everyday exploited as mere commodities, in the current context of capitalism and neoliberal ideology.
\end{abstract}

Keywords: affection, image, childhood, social struggle, neoliberalism

La niñez es vista desde muchos ámbitos -familiares, educativos, sociales, culturales, económicos, etc.- como portadora de esperanzas.

Su apertura a un futuro por realizar con los riesgos y contingencias que ello pueda acarrear, hace que la niñez sea considerada como objeto de profundo cuidado. 


\section{Alguns aportes teóricos para se refletir as imagens da injustiça social e do sofrimento vividos na infância}

Em Spinoza (1632-1677)3, vislumbramos a potência de agir dos sujeitos, em função dos afetos $^{4}$ envolvidos nas relações humanas. Como o filósofo concebe:

o corpo humano compõe-se de muitos indivíduos (de natureza diferente), cada um dos quais é também altamente composto [...] Os indivíduos que compõem o corpo humano e, conseqüentemente, o próprio corpo humano, são afetados ${ }^{5}$ pelos corpos exteriores de muitas maneiras [...] (Spinoza, 2011, p. 66).

Com a crença monista de que razão e emoção não são categorias em si, mas existem em posição relacional e complementar, Spinoza (2011) aponta para o fato de que "a mente poderá considerar como presentes, ainda que não existam nem estejam presentes, aqueles corpos exteriores pelos quais o corpo humano foi uma vez afetado" (p. 67). Será, portanto, neste sentido, que a visão espinosana leva-nos a considerar que o corpo humano pode ser afetado por meios diversos (inclusive através das imagens e fotografias, como aqui enfatizamos ${ }^{6}$ ), pelos quais a sua potência de agir é aumentada ou diminuída, ainda que outros tantos não alterem essa potência7. Esta é a virtude do corpo. Como salienta Gleizer (2005, p.22), para Spinoza, "a alma é a idéia do corpo". Nessa relação indissociável entre corpo e alma ${ }^{8}$ (totalidades compostas e não meros agregados), a possibilidade de virtude da mente (seu conatus ${ }^{9}$ próprio) será justamente pensar, e sua força interior estará relacionada à sua capacidade para interpretar as

3 Spinoza ou Espinosa, como será apresentado no texto e nas referências.

$4 \quad$ Sem a pretensão de esgotar a complexidade da obra espinosana nesse âmbito, vale ressaltar que para esse filósofo, os afetos são uma transição de intensidade, ou seja, a passagem de um estado de potência a outro, promovidos pelas afeç̧ões que o corpo e a mente recebem na existência (Cf. Espinosa, 1957, parte III, apud Sawaia, 2009, p.367). Como concebe, os afetos têm duas dimensões: as modificações no corpo e mente na forma de emoções e sentimentos e a da experiência da afetação (afecção), isto é, o poder de ser afetado (Sawaia, idem, p. 367).

$5 \quad$ Grifo das autoras.

6 Concebemos a imagem a partir dos pressupostos de Runge Peña (2012), quando argumenta que: "Las imágenes, cuando se materializan, es decir, cuando se concretan en muestras pictóricas se vuelven portadoras y productoras par excellence de un sentido individual y socio-cultural. En tanto producto humano, las imágenes se pueden concebir como una forma muy especial de praxis cultural que expresa de un modo particular la asimilación, apropiación, elaboración y reelaboración de ciertos conocimientos, sentires y saberes. De acuerdo con eso, dichas imágenes materiales son siempre más que simples imágenes y, por tanto, no se pueden considerar, ni como el simple reflejo de un fenómeno de base (reproducción de una realidad inmediata), ni como la manifestación exclusiva de un cierto mundo interior (intención escondida del autor). La imágenes al (re)configurarse materialmente se tienen que (re)acomodar dentro de un mundo de sentido codificado socio-culturalmente -sin que por ello se agoten totalmente en la gramática de ese mundo y en su manifestación" (p.2).

$7 \quad$ Postulado 1 de Spinoza (2011) - A origem e a natureza dos afetos (Parte III da Ética).

$8 \quad$ Para Spinoza, a alma é uma totalidade mental, como destaca Gleizer (op.cit.).

9 Trata-se da chave da ética em Spinoza (Parte IV da Ética). É um fundamento central da virtude e refere-se a uma força interna e a um esforço do indivíduo em se manter, conservar, preservar, ser feliz, desejar ser, agir, viver, existir em ato. (cf. Spinoza, 2011). 
imagens de seu corpo e dos corpos exteriores, para a partir delas se chegar às ideias adequadas, das quais essa capacidade/virtude é a única causa, como nos lembra Chauí (2011) a respeito das concepções espinosanas. Nesses termos, a autora também salienta:

passar da condição de causa inadequada à de causa adequada exige passarmos das ideias inadequadas às adequadas ${ }^{\mathbf{1 0}}$, de sorte que, para nossa mente, conhecer é agir e agir é conhecer. Um desejo só se encontra em nossa mente ao mesmo tempo em que a ideia de coisa desejada. (CHAUÍ, 2011, p. 96)

De forma breve e sucinta, então, a ética estará na possibilidade de fortalecimento do conatus (força para existir) "para que se torne causa adequada dos apetites e imagens do corpo e dos desejos e ideias da mente" (CHAUÍ, 2011, p. 97). Em última análise, o conhecimento verdadeiro ensina que a alegria - e todos os afetos relacionados à mesma - ainda que passiva, é o sentimento do aumento do conatus. Spinoza (2011, parte IV da Ética) estabelecerá ainda uma distinção entre as paixões tristes e as paixões alegres:

a força do desejo que surge da alegria deve ser definida pela potência humana $\mathbf{e}$, ao mesmo tempo, pela potência da causa exterior ${ }^{11}$, enquanto a força do desejo que surge da tristeza deve ser definida exclusivamente pela potência humana. O primeiro desejo é, portanto, mais forte que o último (p. 168)

Diante deste cenário, podemos argumentar que a "infância preservada/amparada" e suas imagens veiculadas (compreendidas como unidade de análise), da forma como concebemos o cuidado e os afetos em nosso momento histórico ${ }^{12}$, afetariam positivamente o coletivo, trazendo as chamadas paixões fortes. Assim, o ser humano poderia ser acometido por um sentimento que Spinoza denomina "imitação afetiva". Sob essa afecção, o indivíduo, a partir da semelhança do corpo do outro com o seu próprio, passa a acreditar que ele sofre de seus mesmos sentimentos, assim como deseja seus

10 Grifos nossos. Embora não seja nossa pretensão aprofundar essa dimensão, cumpre salientar que, na visão espinosana, a consciência começa naturalmente pela imaginação, pois para o autor o conhecimento inadequado é próprio à imaginação, vive as afeç̧ões do corpo como a ideia desses "traços" em que se misturam a ideia do corpo afetado e a ideia do corpo que afeta (HIZK, 2006).

11 Grifos nossos.

12 Refere-se aqui à mudança nas formas de tratamento e relacionamento social adulto-criança, ao longo de alguns séculos. Para Áries (1981), os maus-tratos com crianças, praticamente, existiram a partir do nascimento da experiência humana (infanticídio bastante comum nas civilizações antigas, assim como as crianças eram mortas ou abandonadas para que morressem desnutridas ou devoradas por animais, por motivos como: equilíbrio de sexos, medida econômica nos grandes flagelos, por não suportarem longas caminhadas, por questões de cunho religioso, por ser direito do pai reconhecer ou não o direito à vida de seu filho ("Jus vitae et nasci"- Roma, cf. SCHERER e SCHERER, 2000). Vemos aparecer no século XV a "figura infantil" como a representação do ingênuo, do inocente, do bom, em oposição à violência; no entanto, o século XVI traz novamente a característica do tratamento bastante violento para com as crianças e perdura por muitos e muitos anos.

Deste modo, a noção de que a criança precisa ser cuidada e amparada é relativamente recente, ou seja, começa a se concretizar a partir do século XX. 
próprios desejos. Reconhece também sua própria passividade no outro e, assim, alguns dos primeiros sentimentos causados pela imitação afetiva seriam a piedade $e$ comiseração.

Spinoza (1965, p. 269-Proposição L) nos diz que a piedade é um mal em si mesma e inútil no homem que vive sob a direção da razão. Ao seu ver, a piedade faz correspondência ao sentimento de tristeza, quando nos tocamos de comiseração diante da miséria alheia. Da mesma forma, a tristeza seria um mal em si, não trazendo utilidade ou benefícios ao homem.

Nessa concepção, através da piedade e comiseração, ao imaginar que o outro sofre de tais males, nasce o amor e o ódio a um terceiro, que causa a alegria ou tristeza daquele outro com quem se identificou.

Neste contexto, a benevolência representa justamente o desejo de usar todo o poder para destruir a causa da tristeza do outro. Neste contexto, indaga-se sobre as imagens e fotografias que evidenciam a dor e o sofrimento vividos na infância. Especificamente, podem mobilizar esse sentimento coletiva e/ou individualmente e fortalecer meios de superação frente às injustiças sociais, ou seja, podem deflagar, efetivamente, movimentos de lutas sociais nesse sentido? Pensemos, para tanto, também nas representações de infância que podem balizar nossas perspectivas, diante do exposto. Assim, embora não se pretenda aqui aprofundar as questões histórico-culturais envolvidas na concepção atual de infância, faz-se importante destacar que nem sempre a criança foi concebida como o centro da formação familiar ou como alguém que merecesse cuidados, atenção e "afetos elaborados" como o amor e o carinho.

Trazendo para esse cenário a questão das imagens e suas possíveis significações/ sentidos e impactos, Malosetti Costa (2012) nos diz a respeito da capacidade que têm certas "configurações visuais poderosas de 'contaminar' ou atrair novas imagens, de capturar a atenção e persistir na memória coletiva, encarnando ideias e sentimentos $\operatorname{complexos}^{13 \prime \prime}($ p. 1$)$

Malosetti Costa (2012) destaca o poder que exibem certas imagens, porque persistem na memória e podem ser reativadas depois de longos períodos, bem como promover novas vivências e pensamentos. Para a autora:

13 Tradução e grifo das autoras. 
El poder de las imágenes, su capacidad para ser veneradas, despertar devociones y sostener creencias, generar violencia, ser odiadas, temidas y hasta destruidas, es algo que parece caer por fuera de la institución 'arte', desbordando sus circuitos y mecanismos de legitimación en las sociedades occidentales modernas (p.1).

Apoiando-se nas ideias de Louis Marin, a autora enfatiza que o poder de uma imagem reside nela mesma, ainda que sua eficácia só se torne aparente em suas inscrições históricas pontuais (Marin,1991, 1993, citado por MALOSETTI COSTA, 2012).

Em alguma instância, nessa direção, poderíamos refletir sobre o papel de tais imagens na cultura (atravessadas pela questão afetiva), do ponto de vista político e ideológico, especificamente, sobre a questão da "captura" de cenas do cotidiano de crianças e seu sofrimento. Na perspectiva de Carli $(2011)^{14}$

En el caso de las fotografías con niños, el debate se extrema en la medida en que son objetos por excelencia para retratar guerras, hambrunas y violencias. Ese debate resulta complejo también si nos detenemos en el espectador de imágenes de niños. Si recuperamos la pregunta de Sontag acerca de qué significa ser espectador de calamidades, la cuestión sería: ¿qué significa ser espectador de imágenes de niños, cómo se ubica el espectadoradulto, qué conlleva esa mirada, solo se trata de contemplación o implica algún tipo de responsabilidad ${ }^{15}$ ? ( $p$. 168).

É neste contexto, portanto, que o presente trabalho tensiona a questão da exposição das imagens da dor/ sofrimento na/da infância como potência de ação para transformações sociais e/ou como espetáculo e banalização do mal sofrido pelo outro.

Elege-se aqui a fotografia nesse trabalho de "captura" das imagens da infância, pelos motivos expostos por Benjamin (1982:63, citado por BRAVO,2012), pois o advento da fotografia pode ser pensado em paralelo à impressão, dada a capacidade de ambos os dispositivos técnicos em reproduzir conteúdo em larga escala, para entrar no mercado capitalista, multiplicando e alterando substancialmente o modo de circulação de imagens. Para Bravo (2012):

En ambos casos el canal óptico, pensado como un componente central de la experiencia moderna, constituye el sentido privilegiado [...] La fotografía constituyó una renovación enorme, y tanto por su capacidad de ser reproducida y alcanzar una

\footnotetext{
14 As autoras agradecem pelos excertos alocados na $1^{a}$. Oficina (Taller I) de discussão do curso Educação, Imagens e mídia, da Flacso/ Argentina, referentes à obra de Carli (op.cit).

15

Grifos das autoras.
} 
audiencia masiva como por su lealtad con el referente, tuvo cierto protagonismo en la difusión de imágenes de la identidad colectiva (BRAVO, 2012, parte II - Fotos e corpos)

Assim, para o referido autor, as imagens têm uma maior "acentuação" histórica, pois estão ligadas ao tempo, inseridas nele e não cessam de evocá-lo. A seguir, com base no exposto, portanto, discutiremos alguns aspectos dos impactos dessas fotografias acerca da infância, no que se refere à deflagração da injustiça social - em alguns casos a constituição de movimentos de resistência e luta frente à mesma - e a linha tênue desse panorama com a mercantilização e consumo das imagens, na atual sociedade capitalista, onde os preceitos do neoliberalismo econômico influenciam enormemente todos os âmbitos da cultura (portanto no que se refere também às constituições subjetivas), através de seu aparato ideológico ${ }^{16}$.

\section{Algumas questões trazidas pelas imagens do sofrimento e da dor na/da infância}

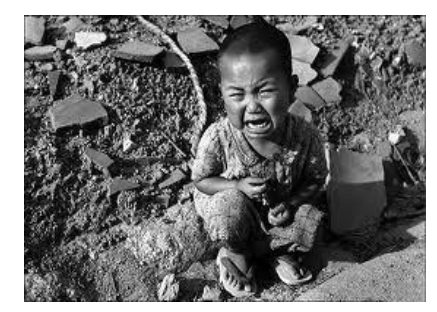

Figura.01 - $\underline{\text { Hiroshima }}^{17}$

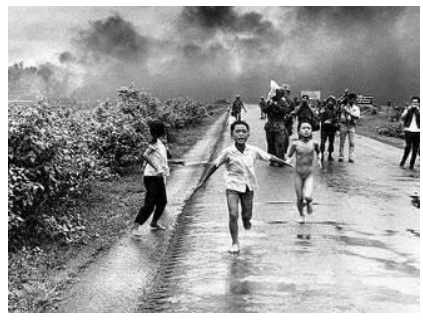

Figura.02 - TrangBang ${ }^{18}$ (Vietnam)

Em recente discussão ${ }^{19}$ a respeito das imagens sobre a infância, onde a dor o sofrimento estão estampados e veiculados pela mídia, um dos membros envolvidos na temática (e não foi o único a evidenciar a posição que segue), argumentou em fórum virtual:

La publicación de estas fotos tiene una justificación, dada por los voceros del periodismo: Son noticia, son coyuntura, son denuncia. Pero, yo me pregunto: ¿Es absolutamente necesario verlas? ${ }^{20}$ $Y$ aquí debemos plantearnos nuestro rol como espectadores. Espectadores de la miseria, de lo íntimo y privado, de situaciones

\footnotetext{
16 Não temos a intenção de discutir de forma detalhada as relações entre capitalismo, neoliberalismo e ideologia no presente trabalho, muito embora consideremos de fundamental importância a compreensão desse contexto para a "leitura das imagens" por parte dos sujeitos e possíveis (des)articulações políticas, ou seja, dado esse cenário, como podemos pensar no que as imagens do cotidiano (i)mobilizam os sujeitos? Ver a respeito da relação mencionada em Chauí (1980), Lombardi (2001), Lombardi e Sanfelice (2007), Lombardi, 2012), por exemplo.

${ }_{17}$ Criança vítima da Bomba Atômica lançada pela Força Aérea Americana sobre a cidade, 6/8/1945 (disponível em: http://colunas.revistaepocanegocios.globo.com/lospantones/2011/05/06/testemunha-ocularda-historia/)

18 Disponível em http://criticaehistoria.blogspot.com.br/2011/08/guerra-do-vietna-o-conflitosangrento.html

$19 \mathrm{Na}$ Oficina virtual (Taller) aberto por Ana Abramowski, a respeito do poder das imagens, no curso Educação, Imagens e Mídicas (Flacso/Argentina).

20 Grifos das autoras.
} 
marginales y extremas. Espectadores del espectáculo (Sontag Dixit). Me resuenan las imágenes de toda la secuencia previa y post terremoto y tsunami en Japón, una suerte de videojuego real, y cómo hipnotizados, narcotizados casi, observamos morir gente en vivo y directo. Al ver estas fotos o videos nos situamos del otro lado, del afuera. Digo, desde la posición de que "Esto no me pasa a mí". (Con una mezcla de alivio y morbo). (G.V.06/07/2012)

Assim, um desses membros também partilha da ideia de que ao nos colocarmos diante dessas imagens infantis podemos "nos situar do lado de fora", ou seja, tender a acreditar que "isso - o mal sofrido pelo outro - não se passa comigo", numa mistura de alívio e morbidez.

Diante dessa discussão, podemos concordar em alguma medida sobre os referenciais que o participante em questão aponta, onde as imagens da infância e sofrimento incorporado pela injustiça social - atrelado aos clichês - são a materialização da banalização do mal sofrido pelo outro, num contexto também mercantilista da dor e do sofrimento. Assim, "vende-se" e "consome-se" qualquer ideia nesse modelo (principalmente pela mídia dita "popular"?).

Diante de tais aspectos, a exposição das imagens com sofrimento infantil seria uma forma de estratégia de denúncia - com possibilidade de organização civil para luta e transformação sociais - ou se refere a um instrumento ideológico que banaliza, naturaliza e legitima a violência e as injustiças sociais?

Numa visão mais crítica, a produção de imagens não seria diferente da produção de automóveis ou hambúrgueres. Tal produção, por conseguinte, não é nada mais ou menos do que um conjunto de atividades específicas voltadas para a produção de um bem, neste caso, a categoria de imagens - apoiadas por uma série de ações políticas que criam condições para permitir que essas atividades produtivas tenham lugar e sejam sustentadas por um discurso que dá legitimidade a toda empresa que as utilizem (jornais, revistas, livros, etc).

O capitalismo tardio vive sua globalização em busca de legitimação (HABERMAS, 2002d), transformando as formas sociais de interação em relações de consumo e a cultura em commodities (Harvey, 2006 apud ZIZEK, 2011 ).

Será também nesse sentido que Sawaia (2011) argumentará que renda e poder, pobreza e exclusão social são categorias decisivas para a compreensão da sociedade capitalista desde o seu processo de constituição (AGAMBEN, 2002, apud SAWAIA, 2011). 
Como substrato e força motriz desse modelo, a ideologia modela também a constituição do sujeito e as produções de sentidos. Para tanto, a ideologia interpela indivíduos como sujeitos históricos (tira-lhes ou reduz as possibilidades de criticidade e a conscientização) e a fim de assegurar o funcionamento do ideário capitalista, ela promove o assujeitamento dos mesmos, uma vez que esses passam a ter a impressão de exercer a sua própria vontade. É neste sentido que SAWAIA (1995) destaca que a consciência deve ser considerada na sua forma de conhecimento explicativo, como também no seu aspecto intuitivo-emocional e o processo de conscientização deve contemplar desejos, necessidades e emoções individuais e coletivas.

Em Spinoza - que desenvolveu sua filosofia da alegria para combater a filosofia do ressentimento e da redenção da Idade Média (que seriam superstições que manteriam a servidão pelo sistema afetivo do medo e da esperança) - já vislumbramos a essência dessa questão que tem apenas se modificado ao longo da história, mas não desaparecido.

Recuperar essa filosofia hoje, na civilização da mitologia eudemonista - isto é, da ideologia da felicidade neoliberal individualista ou da infantilização coletiva feliz, na concepção de Bove (2010, p.50), é um ato de resistência ideológica. O autor, à luz de Espinosa, explica que não há felicidade em estado puro. Afetividade tem estatura ontológica e, ao mesmo tempo, política, pois há equivalência entre ser e viver. A alegria é criação, poder de agir e não meramente reagir ao outro.

A consciência/sentimento de que nossa potência de passar da passividade à atividade só é possível por meio do outro que nos torna comprometidos socialmente, não por obrigação, mas como ontologia. E são os afetos os responsáveis pela união dos esforços (conatus), em nos fazermos um, como se fôssemos uma única mente e um único corpo. Essa união de corpos e mentes constitui um sujeito político coletivo, a "multitudo" (ESPINOSA, 1977, IV, VII e VIII), categoria política fundamental, pois, como afirma Espinosa, o desejo de resistência nasce do sentimento de indignação. Mas resistir não é só se indignar. O direito de derrubar a tirania depende da força para fazê-lo. Essa força, em situação de desmesura do poder, depende de uma potência de agir coletiva conquistada pela união de conatus, a qual, por sua vez, é favorecida quando a lógica dos afetos permite a percepção da amizade e da generosidade como algo útil (CHAUÍ, 2003, p. 250). 
Lembrando uma parte importante da obra de Sebastião Salgado ${ }^{21}$, por exemplo, não poderíamos nos mobilizar para a luta e a resistência, em relação ao sofrimento vivenciado pela infância? Porque justamente são imagens, que também podem (e nesse caso, foram), num movimento contrário ao já referido, ser "bem exploradas", já que retratam o cotidiano em sua perversidade real, em oposição à alienação no mundo ${ }^{22}$.

Nesta direção, Spinoza (2011), em sua Ética, chama-nos a atenção para o fato de que há tantas espécies de afetos quantas são as espécies de objetos pelos quais somos afetados e que os sujeitos são afetados de diferentes maneiras por um único e mesmo objeto (Proposição 33 - Parte IV). Será, portanto, para Spinoza, na tomada de consciência (a partir dos afetos) que o homens poderiam se mobilizar, agir, isto é, apenas à medida que vivessem sob a condução da razão.

\section{As imagens do cotidiano, conscientização e lutas sociais: interlocução possível?}

Sawaia (2009) lembra que o indivíduo alienado não só não reconhece o poder externo que o domina, mas o deseja e se identifica com ele, perdendo a referência do seu conatus e, justamente por isso, provoca sua própria destruição ou a destruição do outro. A alienação torna cada um contrário a todos os outros, cada qual imaginando satisfazer seu desejo com a destruição do outro, percebido como obstáculo aos seus desejos. E em que, então, as imagens do cotidiano nos (i)mobilizam, particularmente quando trazem as crianças?

Talvez tenha sido nesse sentido que outro membro do fórum citado argumentou, a respeito do bombardeio no Vietnam (ocorrido em Trang Bang), em 1972, em que a menina nua e frágil, Kim Phuc, eternizou o sofrimento e a inocência das crianças nessas situações de flagelo humano:

Creo que la imagen materializa la desesperación de las víctimas y, al mismo tiempo, nos lleva a construir mentalmente la imagen de sus victimarios, dos facetas contradictorias del ser humano. Sin duda, se trata de una imagen "fetiche" por su capacidad de atraer nuestra mirada gracias al temor que nos causa hasta hoy. Nuestros ojos no pasan impunemente frente a ese tipo de imagen ${ }^{23}$. (A.T.A. - 15/07/2012)

$21 \quad$ A esse respeito, ver:

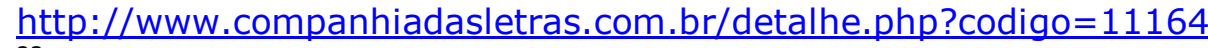

22 Sontag (2011) discute o trabalho realizado por Sebastião Salgado, tecendo várias críticas também à sua obra.

23 Grifos das autoras. 
Sem a intenção de esgotar tal discussão, vale retomarmos a questão da possível melancolia que invade grande parte dos "(ex/es)pectadores" dessas imagens. Para Chauí, esse afeto é o risco de deixarmos de ser o que somos, "de perda não apenas do sentido de nossa existência, mas de nossa essência" (CHAUÍ, 2011, p. 98). Por outro lado, a melancolia pode mobilizar uma exigência bastante grande: que o conatus seja virtus, isto é, "virtude ou força de conservação do que está em vias de se perder" (p. 98).

É nesse campo polissêmico e multifacetado que Sontag (2003) aponta que a foto dá sinais imbricados: "Pare isto, ela exige. Mas também exclama: Que espetáculo!" (p. 66). Assim, para a autora, as fotos que retratam sofrimento não deveriam ser belas, assim como as legendas não deveriam pregar moral. Neste contexto, para apresentar uma denúncia e talvez modificar padrões de comportamento, os fotógrafos recorrem frequentemente à "terapia de choque". Contudo, Sontag alerta para o fato de que o choque pode enfraquecer, ou seja, pelo excesso às imagens violentas, por exemplo, as pessoas podem se adaptar e habituar ao horror, assim como na vida real. A possibilidade estaria nos casos em que a repetida exposição àquilo que choca, entristece, consterna não esgotaria a capacidade de reação compassiva, no dizer de Sontag (2003).

Para a autora, a familiaridade de certas fotos nos possibilita a construção de ideias do presente e do passado imediato, traçando rotas de referência e servindo como totens de causa: "um sentimento tem mais chance de se cristalizar em torno de uma foto do que um lema verbal" (p. 72).

Sontag (2003) provoca-nos a pensar sobre o que significa olhar tais fotos, sobre a capacidade de compreender aquilo que elas mostram. Para a autora, de fato, "a maioria das imagens de corpos torturados e mutilados suscita, na verdade, um interesse lascivo" (p. 80). Temos, portanto, um apetite por cenas de degradação, dor e mutilação. O importante, do ponto de vista trazido aqui, é que Sontag (2003) defende a ideia de que as pessoas, muitas vezes, mostram-se incapazes de sentir os sofrimentos de outros sujeitos. Assim, ela diz que a despeito de toda a sedução voyeurística, parece normal para as pessoas esquivarem-se de pensar sobre a dor alheia, mesmo quando os outros são pessoas com as quais seria razoavelmente fácil essa identificação. Isso vai se dever, fundamentalmente, ao medo que as pessoas sentem, não apenas significando que se tornaram indiferentes. Sontag salienta: "a compaixão é uma emoção instável. Ela precisa ser traduzida em ação, do contrário definha" (p. 85). 
Assim, pelo "bombardeio" midiático dessas imagens de sofrimento (no que se refere à quantidade apenas) as pessoas não se insensibilizariam. Para a autora, seria a passividade que embotaria o sentimento de solidariedade e daria lugar aos sentimentos de raiva e frustração. Para escaparmos dessa "indigestão emocional", proclamamos nossa inocência diante das tragédias alheias: sentimos não ser cúmplices daquilo que causou o sofrimento do outro, na mesma medida em que nos solidarizamos, de forma geral.

Como se observa, pelo pensamento espinosano, vencer a melancolia é uma exigência ética, uma vez que a mesma coloca em prova a nossa própria humanidade. Em última análise, poderíamos questionar: em nosso momento histórico, com os apelos midiáticos e os processos de individualização crescentes ${ }^{24}$, podemos ainda ser afetados com o mal sofrido pelo outro e agir no combate à injustiça social? Podemos ser éticos e pensar no bem comum antes de nós mesmos?

Sontag (2003), nesse âmbito, diz que talvez prefiramos não pensar sobre o modo como os nossos privilégios estão associados à miséria e ao sofrimento do outro, mas essa é também uma tarefa para a qual as imagens dolorosas fornecem caminhos que podem/ precisam ser trilhados. As imagens nos ajudam, portanto, no mínimo, a refletir sobre a nossa própria ética (individual e coletiva), tensionando os papéis do que venha a ser a adultez e a infância, balizados pelos jogos de poder.

\section{Referências}

AGAMBEN, G. Homo Sacer: o poder soberano e a vida nua. Belo Horizonte: UFMG, 2002.

ARIÈS, P. História social da criança e da família (L'Enfant et la Vie familiale sous I'Ancien Régime). 2. ed. Rio de Janeiro: Editora LTC, 1981.

BOVE, L. Espinosa e a Psicologia Social: ensaios de ontologia política e antropogênese. Belo Horizonte: Autêntica, 2010.

BRAVO, A. F. Regímenes de visibilidad. Imágenes de los indígenas en la formación de la identidad colectiva argentina. Flacso Virtual, 2012. Clase 7 do Diploma Educación, Imagenes y medios.

CARLI, S. La memoria de la infancia: estudios sobre historia, cultura y sociedad. $1^{a}$. Ed. Buenos Aires: Paidós, 2011.

24 Neste sentido, ver Sawaia (2001), Jodelet (2009) e Heller (1982), por exemplo. 
CHAUÍ, M. Desejo, paixão e ação na ética de Espinosa. SP: Companhia das Letras, 2011.

o que é ideologia? 1980. Disponível em:

http://www.nhu.ufms.br/Bioetica/Textos/Livros/O\%20QUE\%20\%C3\%89\%20IDEOLOGIA

\%20-Marilena\%20Chaui.pdf. Acesso em 14/11.2012.

ESPINOSA, B. Tratado Político. Trad. de Manuel de Castro. Lisboa: Editorial Estampa, 1977.

GLEIZER, M.A. Espinosa \& a afetividade humana. RJ: Jorge Zahar Ed. 2005. (Passoa-passo; 53).

HABERMAS, J. O que é pragmática universal? In: HABERMAS, J. Racionalidade e Comunicação. Tradução de Paulo Rodrigues. Lisboa, Edições 70, pp. 9- 102 [ publicado originalmente escrito em 1976].

HARDT, M. Gilles Deleuze: um aprendizado em filosofia. São Paulo: Ed. 34, 1996.

HELLER, A. Para mudar a vida: felicidade, liberdade e democracia. SP: Ed. Brasiliense, 1982.

Lukács y La sagrada família. In FEHÉR, F e HELLER, A. (Ed.).Dialéctica de las formas: el pensamiento estético de la Escuela de Budapeste. Barcelona: Península, 1987.

JODELET, D. o movimento de retorno ao sujeito e a abordagem das representações sociais. Sociedade e Estado, Brasília, v. 24, n. 3, p. 679-712, set./dez. 2009.

LOMBARDI, J.C. Globalização, pós-modernidade e educação: história, filosofia e temas transversais. Campinas/SP: Autores Associados, HISTEDBR; Caçador/SC: UnC, 2001.

e SANFELICE, José Luís. Liberalismo e educação em debate.

Campinas/SP: Autores Associados, HISTEDBR, 2007.

Embates marxistas: apontamentos sobre a pós-modernidade e a crise terminal do capitalismo. Campinas, SP: Librum, Navegando, 2012. Disponível em: http://eventohistedbr.com.br/editora/wpcontent/uploads/2012/07/lombardi_embatesmarxistas_navegando_ebook.pdf 
MALOSETTI COSTA, L. El poder de las imágenes. Flacso Virtual, 2012. Clase 8 do Diploma Educación, Imagenes y medios.

RIZK, H. Compreender Espinosa. SP: Vozes, 2006.

SAWAIA, B. B. Psicologia e desigualdade social: uma reflexão sobre liberdade e transformação social. Psicologia \& Sociedade, 21 (3): 364-372, 2009.

(org.). As artimanhas da exclusão: análise psicossocial e ética da desigualdade social. 3a. Ed. SP: Vozes, 2001.

Da consciência à potência de ação: um movimento possível do sujeito revolucionário na psicologia social laneana. In: MEDRADO, B.; GALINDO, W. (Orgs.). Psicologia social e seus Movimentos: 30 anos de ABRAPSO. Recife: Ed. Universitária da UFPE, 2011, v. , p. 35-53. ( texto elaborado a convite da ABRAPSO).

SCHERER, E.A.; SCHERER, Z. A. P. A criança maltratada: uma revisão da literatura. Rev. Latino-Am. Enfermagem. Rev. Latino-Am. Enfermagem v.8 n.4 Ribeirão Preto ago. 2000. Disponível em: http://www.scielo.br/scielo.php?script=sci arttext\&pid=S0104$11692000000400004 \&$ Ing=pt\&nrm=iso. Acesso em 02/08/2012.

SONTAG, S. Diante da dor dos outros. SP: Companhia das Letras, 2003.

SPINOZA, B. Ética. 2a. Ed. Belo Horizonte: Autêntica Editora, 2011.

ZIZEK, S. Em defesa das causas perdidas. SP: Boitempo Editorial, 2011.

Naiara Roberta Vicente de Matos

Heloísa Andreia de Matos Lins

Doutoranda em Psicologia Social - PUC/SP, Mestre em Psicologia Social - PUC/SP (Bolsista CNPq). Graduada em Terapia Ocupacional (PUC Campinas - 2000). Profa. Adjunta da PósGraduação da Faculdade Anhanguera de Guarulhos.Email: naiara_m@hotmail.com

Profa. Dra. do Departamento de Psicologia Educacional da Faculdade de Educação da UNICAMP. Membro do Grupo de Pesquisa ALLE - Alfabetização, Leitura e Escrita, na mesma instituição. Email: hmlins@unicamp.br

Recebido em: 05/09/2013

Aprovado em: 01/03/2014 